\title{
ANALYSIS OF OIL POINT THRESHOLD INDICATORS OF BULK RAPESEEDS AND SUNFLOWER SEEDS UNDER COMPRESSION LOADING
}

\author{
Cimen Demirel, David Herak, Abraham Kabutey, Oldrich Dajbych \\ Czech University of Life Sciences Prague, Czech Republic \\ demirel@tf.czu.cz, herak@tf.czu.cz, kabutey@tf.czu.cz, dajbych@tf.czu.cz
}

\begin{abstract}
The article evaluates the oil point parameters of samples of bulk rapeseeds and sunflower seeds under compression loading. The oil point is the region where the oil emerges from the seed kernel which requires maximum pressure to recover the maximum oil contained in the bulk seeds. The determination of the maximum pressure, however, requires both the experimental and theoretical analyses of the oil point parameters namely strain, energy, oil yield and gradient volume energy. This information is limited in the literature for bulk oilseeds such as rape and sunflower. In this present study, the oilseeds samples were measured at an initial pressing height of $80 \mathrm{~mm}$ in a pressing vessel of diameter $60 \mathrm{~mm}$. The deformation levels of 30, 35, 40, 45 and $50 \mathrm{~mm}$ were tested for the lower and upper oil points at a speed of $10 \mathrm{~mm} \cdot \mathrm{min}^{-1}$ using the litmus test procedure. The above-mentioned oil point indicators were calculated. The force-deformation curve of the upper oil point was theoretically described by the tangent curve model where the coefficients of the model were determined and statistically analyzed to assess the accuracy of the model using the MathCAD 14 software. The study provides useful information for optimizing the mechanical oil extraction process involving screw presses.
\end{abstract}

Keywords: oilseeds, compression, deformation, strain, energy.

\section{Introduction}

Rape and sunflower are among the oil-bearing crops and fruits as feedstocks for vegetable or edible oil production [1]. The world consumption of vegetable oils is currently at 200 million metric tons annually, driven by high demand for use in food and industrial applications $[1 ; 2]$. Conventionally, the vegetable oil is produced by extraction with an organic solvent alone or by screw pressing before solvent extraction [3]. The oil yield from mechanical pressing is relatively low compared to the solvent extraction which can achieve a crude oil yield of over 96\% [1]. However, the solvent extraction process has major setbacks including high flammability and acute inhalation of the solvent by humans [4]. The mechanical pressing is much safer and environmental-friendly $[1 ; 5]$.

To improve the economic performance of the mechanical pressing, it is important to study the mechanical behaviour of the bulk oilseeds under compression loading [6; 7]. The uniaxial compression process reveals the mechanical behaviour of the bulk oilseeds characterized by the force-deformation curves, oil point thresholds, deformation, strain, deformation energy, unit volume energy and stress relaxation behaviour [8; 9]. These properties are also influenced by the processing factors namely the moisture content, force/pressure, speed, the initial pressing height of bulk seeds, the diameter of pressing vessel, varieties and maturity stages of the bulk oilseeds [10-13].

The present study, however, focuses on identifying the oil point thresholds of bulk rapeseeds and sunflower seeds under compression loading and analyzing mathematically the oil point parameters (oil point force, oil point energy, strain, volume energy, the mass of oil, the theoretical maximum mass of oil, theoretical oil yield and gradient volume energy).

\section{Materials and methods}

Rapeseeds and sunflower seeds were procured from Česká Skalice, Czech Republic. The moisture content of the samples of rapeseeds and sunflower seeds was determined to be $5.30 \pm 0.04 \%$ (w.b.) and $5.16 \pm 0.01 \%$ (w.b.) according to the conventional method by drying the samples of the seeds in the oven at $105^{\circ} \mathrm{C}$ and drying time of $17 \mathrm{~h}[14 ; 15]$. The oil content of the samples was determined to be $31.87 \pm 2.40 \%$ and $33.12 \pm 0.87 \%$ based on the Soxhlet extraction procedure [16-18]. The oil point of the bulk rapeseeds and sunflower seeds was identified from the compression tests using the universal compression testing machine (VEB, ZDM 50, Germany) and pressing vessel of diameter $60 \mathrm{~mm}$ with a plunger. The litmus test principle was used for the oil point identification of the bulk oilseeds [9; 18] at deformation levels from 30 to $50 \mathrm{~mm}$ and at a speed of $10 \mathrm{~mm} \cdot \mathrm{min}^{-1}$. The initial pressing height of the bulk seeds was measured at $80 \mathrm{~mm}$ giving the volume of the bulk seeds in the pressing vessel to be $22.62 \cdot 10^{-5} \mathrm{~m}^{3}$. The tests were repeated twice, and the results averaged. Based on the force and deformation data obtained; the mass of oil, the theoretical mass of oil, 
theoretical oil yield, oil point force, oil point energy, strain, volume of seeds, volume energy and gradient volume energy were determined according to the equations given by $[7 ; 8 ; 19]$. The oil yield is the percentage ratio of the mass of oil output and mass of bulk seeds. The strain is the ratio of deformation to that of the initial pressing height of the sample. The energy is characterized by the area under the force-deformation curve which can be calculated based on the trapezoidal principle. The ratio of the energy to the volume of the bulk seeds in the pressing vessel denotes the volume energy. The gradient volume energy is the ratio of incremental volume energy to that of the mass of output oil. The theoretical description of the force-deformation curve of the samples of bulk rapeseeds and sunflower seeds was done using MathCAD 14 software [20].

\section{Results and discussion}

The results of the experiments are presented in Tables 1 to 5 and Fig. s 1 to 3 respectively. At deformation levels between 30 and $35 \mathrm{~mm}$ for bulk rapeseeds (Table 1) was observed the possibility of the lower oil point region. The lower oil point was noticed at $32 \mathrm{~mm}$ with the corresponding mass of oil, oil point force and energy values of $3.34 \pm 0.01 \mathrm{~g}, 28.13 \pm 0.42 \mathrm{kN}$ and $0.32 \pm 0.03 \mathrm{~kJ}$. The experimental upper oil point was seen at a deformation level of $50 \mathrm{~mm}$ producing $24.45 \pm 0.03 \mathrm{~g}$ of the mass of output oil with the force of $152.54 \pm 10.61 \mathrm{kN}$ and energy of $0.79 \pm 0.00 \mathrm{~kJ}$. In comparison with bulk sunflower seeds (Table 2), there was no oil flow at deformation levels between 30 and $35 \mathrm{~mm}$. The lower oil point was found at a deformation level of $40 \mathrm{~mm}$ (mass of oil: $1.70 \pm 0.13 \mathrm{~g}$; oil point force: $15.47 \pm 1.72 \mathrm{kN}$ and oil point energy: $0.18 \pm 0.01 \mathrm{~kJ}$ ). The experimental upper oil point at deformation level of $50 \mathrm{~mm}$ for sunflower bulk seeds recorded the mass of output oil of $9.61 \pm 0.78 \mathrm{~g}$, force of $34.82 \pm 1.78 \mathrm{kN}$ and energy of $0.37 \pm 0.03 \mathrm{~kJ}$. The lower oil point is the beginning of the oil flow through the cell wall pores whereas the upper oil point is the maximum oil flow through the cell wall pores and the inter-kernel voids of the bulk oilseeds $[9 ; 10 ; 19]$.

The information of oil point of bulk oilseeds is essential for predicting the effective pressure required for oil expression and to know the influence of the applied force/pressure and pressing time on the amount of the output oil in a pressing operation involving a screw/hydraulic press [21;22].

It was observed in Fig. 1 that the serration effect occurred at a force beyond $155.02 \pm 14.15 \mathrm{kN}$ which was marked by the seedcake ejection through the pressing vessel holes. The compression process was stopped at the beginning of the serration effect since no oil would be recovered. The serration effect was seen only in bulk rapeseeds. Similar behaviour was reported by [7,23] where the diameter of the pressing vessel, deformation levels and moisture content caused the serration effect/undulation characteristics on the force-deformation curves of sunflower seeds and kernel as well as rapeseeds. The parameters presented in Tables 3 and 4 are described as follows. From the deformation levels and initial pressing height of the bulk seeds, the strain values were determined which ranged from 0.40 to 0.63 (-). For bulk rapeseeds, the volume energy values ranged from $1406.83 \pm 112.47$ to $13020.43 \pm 732.44 \mathrm{~kJ} \cdot \mathrm{m}^{-3}$ in comparison with bulk sunflower seeds which ranged from $812.77 \pm 54.75$ to $1630.00 \pm 126.51 \mathrm{~kJ} \cdot \mathrm{m}^{-3}$.

Based on the mass of oil recovered and the percentage oil content in the bulk seeds through the Soxhlet extraction method, the theoretical mass of oil of bulk rapeseeds and bulk sunflower seeds was determined to be $45.43 \pm 3.43 \mathrm{~g}$ and $35.02 \pm 0.92 \mathrm{~g}$ respectively. The ratio of the mass of oil to the theoretical mass of oil gives the theoretical oil yield which ranged from $0.07 \pm 0.01$ to $0.54 \pm 0.04$ (-) for both bulk rapeseeds and sunflower bulk seeds. For bulk rapeseeds, the gradient volume energy ranged from $421.88 \pm 34.62$ to $1956.11 \pm 156.06 \mathrm{~kJ} \cdot \mathrm{m}^{-3} \cdot \mathrm{g}^{-1}$. The gradient volume energy for bulk sunflower seeds ranged from $478.24 \pm 3.60$ to $67.67 \pm 15.12 \mathrm{~kJ} \cdot \mathrm{m}^{-3} \cdot \mathrm{g}^{-1}$.

The dependency between mass of oil and deformation levels of the bulk rapeseeds and sunflower seeds was significant $(P<0.05)$ (Fig. 2). Regression equations were obtained at oil points deformation levels for both oilseeds where the theoretical upper oil points were also predicted at theoretical deformation levels of $66.04 \pm 2.99 \mathrm{~mm}$ and $83.58 \pm 4.75 \mathrm{~mm}$ respectively. From the tangent curve model $[18 ; 24 ; 25]$, the experimental force-deformation curve at upper oil point for deformation level of $50 \mathrm{~mm}$ was theoretically described (Fig. 3) by determining the force coefficient of mechanical behaviour, deformation coefficient of mechanical behaviour and fitting curve exponent (Table 5). The fitting curve value for rapeseed and sunflower seeds was found to be 1 . The determined coefficients were significant based on the high coefficient of determination $\left(R^{2}\right)$ values between 0.985 and 1 . The 
significance of the results was also assessed by the fact that P-values were greater than the significant level of 5\% and F-critical values being greater than F-ratio values. Similar results were reported by [19] on Jatropha bulk seeds where the fitting value of 2 was found. This could be due to the variation in moisture content, maturity stage of the seeds and inherent mechanical behaviour of the seeds.

Table 1

Mass of oil, oil point force and oil point energy of rapeseeds

\begin{tabular}{|c|c|c|c|c|c|}
\hline $\begin{array}{c}\text { *Deformation } \\
\boldsymbol{X}, \mathbf{~ m m}\end{array}$ & $\begin{array}{c}\text { Mass of } \\
\text { sample } \boldsymbol{M}_{\boldsymbol{b}}, \mathbf{g}\end{array}$ & $\begin{array}{c}\text { Mass of } \\
\mathbf{s a m p l e ,} \boldsymbol{M}_{\boldsymbol{a}}, \mathbf{g}\end{array}$ & $\begin{array}{c}\text { Mass of oil } \\
\boldsymbol{M}_{\boldsymbol{i} i}, \mathbf{g}\end{array}$ & $\begin{array}{c}\text { Oil point force } \\
\boldsymbol{O}_{\boldsymbol{P F}}, \mathbf{k N}\end{array}$ & $\begin{array}{c}\text { Oil point energy } \\
\boldsymbol{O}_{\boldsymbol{P E}}, \mathbf{k J}\end{array}$ \\
\hline 30 & 142.54 & $142.54 \pm 0.00$ & $0.00 \pm 0.00$ & $22.59 \pm 1.84^{* *}$ & $0.26 \pm 0.03 * *$ \\
\hline 32 & 142.54 & $139.21 \pm 0.01$ & $3.34 \pm 0.01$ & $28.13 \pm 0.42$ & $0.32 \pm 0.03$ \\
\hline 35 & 142.54 & $132.24 \pm 0.01$ & $10.30 \pm 0.01$ & $41.47 \pm 0.31$ & $0.41 \pm 0.07$ \\
\hline 40 & 142.54 & $122.21 \pm 0.01$ & $20.33 \pm 0.01$ & $147.99 \pm 24.17$ & $0.75 \pm 0.10$ \\
\hline 45 & 142.54 & $120.54 \pm 0.03$ & $22.00 \pm 0.03$ & $155.02 \pm 14.15$ & $0.82 \pm 0.01$ \\
\hline 50 & 142.54 & $118.09 \pm 0.03$ & $24.45 \pm 0.03$ & $152.54 \pm 10.61$ & $0.79 \pm 0.00$ \\
\hline
\end{tabular}

* Sample pressing height, $H=80 \mathrm{~mm} ;{ }^{\text {a: }}$ Strain (-); $M_{b}$ : before test; $M_{b}$ : after test; ** without oil flow

Mass of oil, oil point force and oil point energy of sunflower seeds

Table 2

\begin{tabular}{|c|c|c|c|c|c|}
\hline $\begin{array}{c}\text { *Deformation } \\
\boldsymbol{X}, \mathbf{~ m m}\end{array}$ & $\begin{array}{c}\text { Mass of } \\
\text { sample } \boldsymbol{M}_{\boldsymbol{b}},\end{array}$ & $\begin{array}{c}\text { Mass of } \\
\mathbf{g}\end{array}$ & $\begin{array}{c}\text { Mass of oil } \\
\mathbf{M}_{\boldsymbol{o i l}}, \mathbf{g}\end{array}$ & $\begin{array}{c}\text { Oil point force }, \boldsymbol{M}_{\boldsymbol{a}}, \mathbf{g} \\
\boldsymbol{O}_{\boldsymbol{P F}}, \mathbf{k N}\end{array}$ & $\begin{array}{c}\text { Oil point energy } \\
\boldsymbol{O}_{\boldsymbol{P E}}, \mathbf{k J}\end{array}$ \\
\hline 30 & 105.72 & $105.72 \pm 0.00$ & $0.00 \pm 0.00$ & $8.03 \pm 1.80^{* *}$ & $0.10 \pm 0.02^{* *}$ \\
\hline 32 & 105.72 & $105.72 \pm 0.00$ & $0.00 \pm 0.00$ & $7.76 \pm 0.94^{* *}$ & $0.10 \pm 0.02^{* *}$ \\
\hline 35 & 105.72 & $105.72 \pm 0.00$ & $0.00 \pm 0.00$ & $9.25 \pm 0.22^{* *}$ & $0.12 \pm 0.00^{* *}$ \\
\hline 40 & 105.72 & $104.02 \pm 0.13$ & $1.70 \pm 0.13$ & $15.47 \pm 1.72$ & $0.18 \pm 0.01$ \\
\hline 45 & 105.72 & $102.99 \pm 0.01$ & $2.73 \pm 0.01$ & $20.56 \pm 0.94$ & $0.26 \pm 0.02$ \\
\hline 50 & 105.72 & $96.12 \pm 0.78$ & $9.61 \pm 0.78$ & $34.82 \pm 1.78$ & $0.37 \pm 0.03$ \\
\hline
\end{tabular}

* Sample pressing height, $H=80 \mathrm{~mm}$; ${ }^{\text {a }}$ Strain $(-) ; M_{b}$ : before test; $M_{b}$ : after test; ** without oil flow

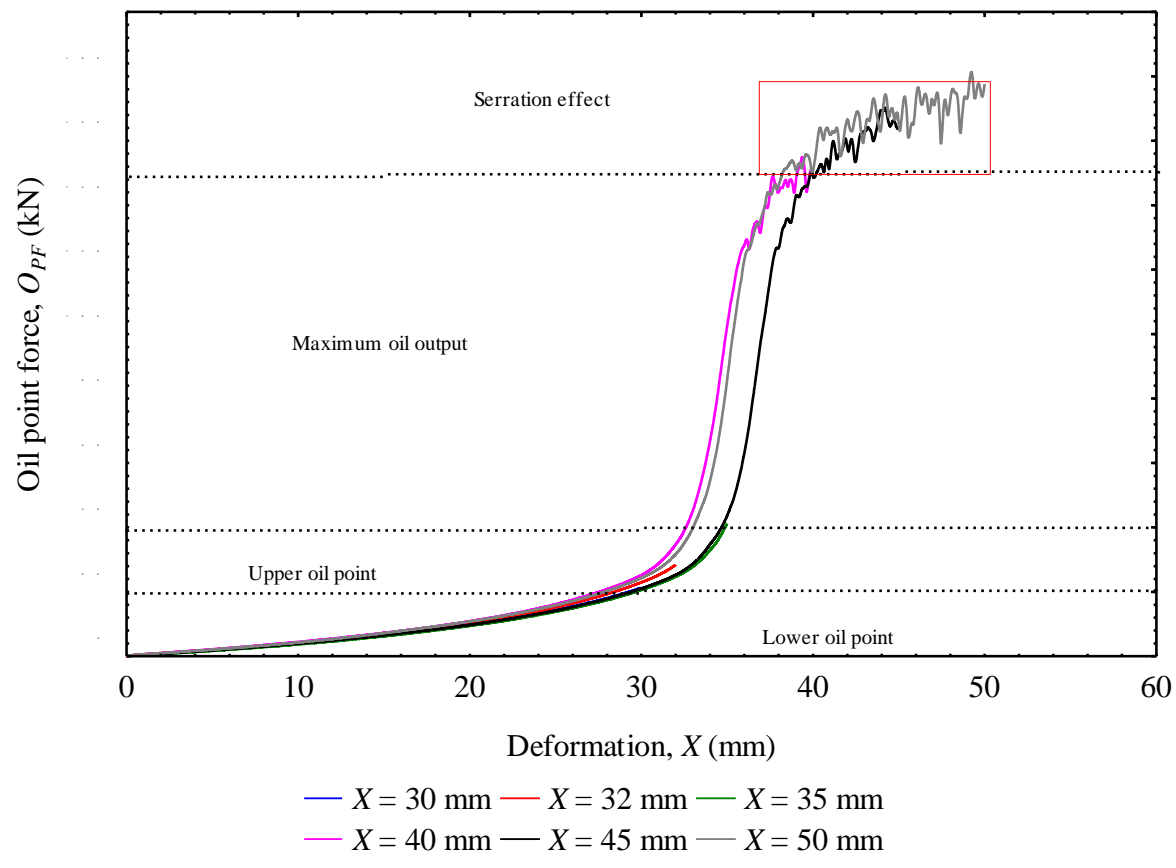

Fig. 1. Identification of oil points, maximum oil output and serration effect of bulk rapeseeds and sunflower seeds at different deformation levels 
Volume energy, theoretical oil yield and gradient volume energy of rapeseeds

Table 3

\begin{tabular}{|c|c|c|c|}
\hline Strain, - & $\begin{array}{c}\text { Volume energy, } \\
\mathbf{k J} \cdot \mathbf{m}^{-3}\end{array}$ & Theoretical oil yield, & $\begin{array}{l}\text { Gradient volume } \\
\text { energy, } \mathrm{kJ} \cdot \mathrm{m}^{-3} \cdot \mathrm{g}^{-1}\end{array}$ \\
\hline 0.40 & $1406.83 \pm 112.47$ & $0.07 \pm 0.01$ & $421.88 \pm 34.62$ \\
\hline 0.44 & $1801.22 \pm 290.55$ & $0.23 \pm 0.02$ & $56.64 \pm 25.62$ \\
\hline 0.50 & $5097.47 \pm 220.89$ & $0.45 \pm 0.03$ & $328.64 \pm 50.99$ \\
\hline 0.56 & $8232.37 \pm 1004.14$ & $0.49 \pm 0.04$ & $1880.36 \pm 749.47$ \\
\hline 0.63 & $13020.43 \pm 732.44$ & $0.54 \pm 0.04$ & $1956.11 \pm 156.06$ \\
\hline
\end{tabular}

Table 4

Volume energy, theoretical oil yield and gradient volume energy of sunflower seeds

\begin{tabular}{|c|c|c|c|}
\hline Strain, - & $\begin{array}{c}\text { Volume energy, } \\
\mathbf{k J} \cdot \mathbf{m}^{-3}\end{array}$ & $\begin{array}{c}\text { Theoretical oil yield, } \\
\text { - }\end{array}$ & $\begin{array}{l}\text { Gradient volume } \\
\text { energy, } \mathrm{kJ} \cdot \mathrm{m}^{-3} \cdot \mathrm{g}^{-1}\end{array}$ \\
\hline 0.50 & $812.77 \pm 54.75$ & $0.05 \pm 0.01$ & $478.24 \pm 3.60$ \\
\hline 0.56 & $1170.84 \pm 76.64$ & $0.08 \pm 0.01$ & $342.11 \pm 80.59$ \\
\hline 0.63 & $1630.00 \pm 126.51$ & $0.27 \pm 0.03$ & $67.67 \pm 15.12$ \\
\hline
\end{tabular}

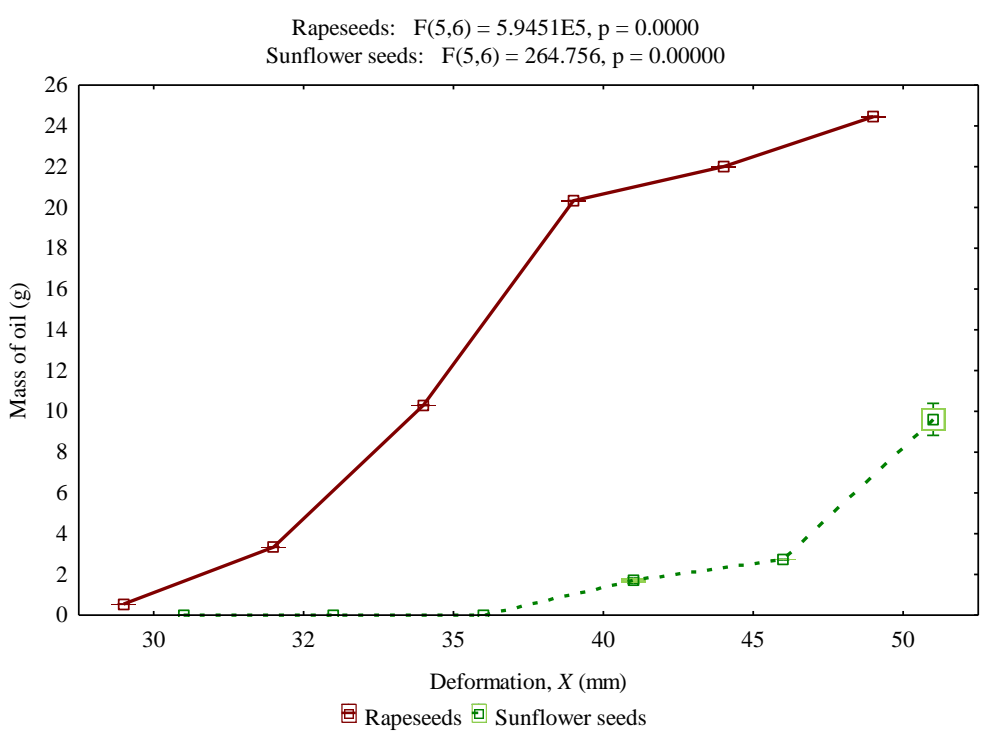

Fig. 2. Dependency between the mass of oil and deformation of bulk rapeseeds and sunflower seeds

Table 5

ANOVA analysis of the determined coefficients of the tangent model for fitting the data of the bulk oilseeds samples.

\begin{tabular}{|c|c|c|c|c|c|c|c|}
\hline $\begin{array}{c}\text { Bulk oilseeds } \\
\text { samples }\end{array}$ & $\boldsymbol{A}, \mathbf{k N}$ & $\boldsymbol{B}, \mathbf{~ m m}^{-\mathbf{1}}$ & $\boldsymbol{n}$ & $\boldsymbol{F}$-ratio & $\boldsymbol{F}$-critical & $\boldsymbol{P}$-value & $\boldsymbol{R}^{\mathbf{2}}$ \\
\hline R1 & 12.505 & 0.034 & 1 & 0.012 & 3.853 & 0.913 & 0.985 \\
\hline R2 & 11.696 & 0.039 & 1 & $4.51 \cdot 10^{-3}$ & 3.854 & 0.946 & 0.995 \\
\hline S1 & 5.478 & 0.028 & 1 & $3.742 \cdot 10^{-3}$ & 3.853 & 0.995 & 1 \\
\hline S2 & 6.199 & 0.028 & 1 & $1.469 \cdot 10^{-6}$ & 3.853 & 0.999 & 1 \\
\hline
\end{tabular}

$A$ is the force coefficient of mechanical behaviour $(\mathrm{kN}), B$ is the deformation coefficient of mechanical behaviour $\left(\mathrm{mm}^{-1}\right), n$ is the fitting curve function exponent (-); R1 and R2: Rapeseeds samples; S1 and S2: Sunflower seeds samples. 


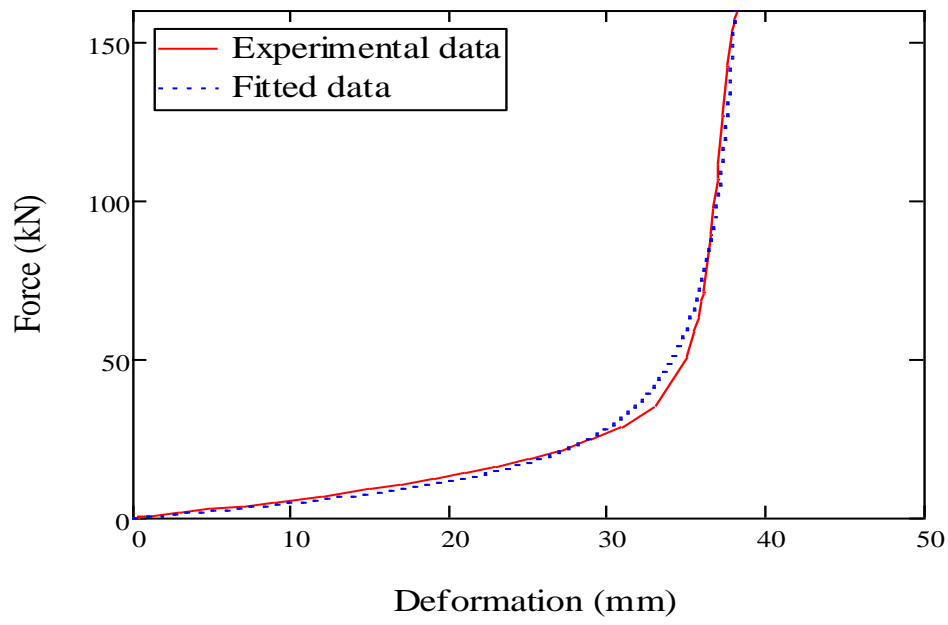

Fig. 3. The experimental and fitted force-deformation curve of bulk rapeseeds (like sunflower seeds) at upper oil points for deformation level of $50 \mathrm{~mm}$

\section{Conclusions}

At bulk samples initial pressing height of $80 \mathrm{~mm}$, speed of $10 \mathrm{~mm} \cdot \mathrm{min}^{-1}$ and pressing vessel of $60 \mathrm{~mm}$ diameter with a plunger; the findings are as follows:

1. The lower oil point for rapeseeds was observed at a deformation level of $32 \mathrm{~mm}$ whereas for sunflower it was noticed at a deformation level of $40 \mathrm{~mm}$.

2. The upper oil point for both oilseeds was recorded at a deformation level of $50 \mathrm{~mm}$ with the corresponding mass of oil of $24.45 \pm 0.03 \mathrm{~g}$ for rapeseeds and $9.61 \pm 0.78 \mathrm{~g}$ for sunflower seeds. This indicates that rapeseeds contain more oil than sunflower seeds.

3. The oil points force for rapeseeds ranged from $28.13 \pm 0.42 \mathrm{kN}$ to $152.54 \pm 10.61 \mathrm{kN}$, and for sunflower seeds, it was between $15.47 \pm 1.72 \mathrm{kN}$ and $34.82 \pm 1.78 \mathrm{kN}$. This indicates that rapeseeds are much harder than sunflower seeds.

4. The deformation levels of $66.04 \pm 2.99 \mathrm{~mm}$ and $83.58 \pm 4.75 \mathrm{~mm}$ were predicted as the theoretical upper oil points for rapeseeds and sunflower seeds.

\section{Acknowledgements}

The authors would like to thank the donors for the financial support (EU, Managing Authority of the Czech Operational Programme Research, Development and Education through the project "supporting the development of international mobility of research staff at CULS Prague", Grant Number: CZ.02.2.69/0.0/0.0/18_053/0016979).

\section{References}

[1] Msanne J., Kim H., Cahoon E.B. Biotechnology tools and applications for development of oilseed crops with healthy vegetable oils. Biochimie, vol. 178, 2020, pp. 4-14.

[2] Oilseeds, World Markets and Trade, United States Department of Agriculture Foreign Agricultural Service, 2020. [online] [21.03.2021] Available at: https://apps.fas.usda.gov/psdonline/circulars/oilseeds.pdf.

[3] Liu J-J., Gasmalla M.A.A., Li P., Yang R. Enzyme-assisted extraction processing from oilseeds: Principle, processing and application. Innovative Food Science and Emerging Technologies, vol. 25, 2016, pp. 184-193.

[4] Wu J., Johnson L., Jung S. Demulsification of oil-rich emulsion from enzyme-assisted aqueous extraction of extruded soybean flakes. Bioresource Technology, vol. 100(2), 2009, pp. 527-533.

[5] de Moura J., Johnson L. Two-stage countercurrent enzyme-assisted aqueous extraction processing of oil and protein from soybeans. Journal of the American Oil Chemists' Society, vol. 86(3), 2009, pp. 283-289. 
[6] Munson-Mcgee S.H. D-optimal experimental designs for uniaxial expression. Journal of. Food Process Engineering, vol. 37, 2014, pp. 248-256.

[7] Divisova M., Herak D., Kabutey A., Sigalingging R., Svatonova T. Deformation curve characteristics of rapeseeds and sunflower seeds under compression loading. Scientia Agriculturae Bohemicae. Vol. 45, 2014, pp. 180-186.

[8] Chakespari A.G., Rajabipour A., Mobli H. Anisotropic relaxation and creep properties of apple (cv. Shafi Abadi and Golab Kohanz). Advanced Journal of Food Science and Technolology. vol. 2, 2010, pp. 200-205.

[9] Faborade M.O., Favier J.F. Identification and significance of the oil-point in seed-oil expression. Journal of Agricultural Engineering Research, vol. 65, 1996, pp. 335-345.

[10] Mrema G.C., McNulty P.B. Mathematical model of mechanical oil expression from oilseeds. Journal of Agricultural Engineering Research, vol. 31, 1985, pp. 361-370.

[11]Deli S., Farah Masturah M., Tajul Aris Y., Wan Nadiah W.A. The effects of physical parameters of the screw press oil expeller on oil yield from Nigella sativa L. seeds. International Food Research Journal, vol. 18, 2011, pp. 1367-1373.

[12] Karaj S. Muller J. Optimizing mechanical oil expression of Jatropha curcas L. seeds with respect to press capacity, oil recovery and energy efficiency. Industrial Crops and Products, 34, 2011, pp. 1010-1016.

[13] Bogaert L., Mathieu H., Mhemdi H., Vorobiev E. Characterization of oilseeds mechanical expression in an instrumented pilot screw press. Industrial Crops and Products, vol. 121, 2018, pp. 106-113.

[14] Blahovec J. Agromatereials Study Guide; Czech University of Life Sciences Prague: Prague, Czech Republic, 2008. pp. 7-8.

[15] ISI. Indian Standard Methods for Analysis of Oilseeds. In Indian Standard Institute; IS:3579; ISI: New Delhi, India, 1966.

[16] Gurkan A.K.G., Kabutey A., Selvi K.C., Hrabe P., Herak D., Frankova, A. Investigation of heating and freezing pretreatments of mechanical, chemical and spectral properties of bulk sunflower seeds and oil. Processes, vol. 8(411), 2020, pp. 1-20.

[17] Danlami J.M., Arsad A., Zaini M.A.A. Characterization and process optimization of castor oil (Ricinus communis L.) extracted by the soxhlet method using polar and non-polar solvents. Journal of Taiwan Institute of Chemical Engineering, vol. 47, 2015, pp. 99-104.

[18] Niu L., Li J., Chen M.S., Xu Z.F. Determination of oil contents in Sacha inchi (Plukenetia volubilis) seeds at different developmental stages by two methods: Soxhlet extraction and time-domain nuclear magnetic resonance. Industrial Crops and Products vol. 56, 2014, pp. 187-190.

[19] Herak D., Kabutey A., Hrabe P. Oil point determination of Jatropha curcas L. bulk seeds under compression loading. Biosystems Engineering, vol. 116, 2013, pp. 470-477.

[20] Pritchard P.J. Mathcad: A tool for engineering problem solving. McGraw-Hill, 1998.

[21] Raji A.O., Favier J.F. Model for the deformation in agricultural and food particulate materials under bulk compressive loading using discrete element method. I: Theory, model development and validation. Journal of Food Engineering, vol. 64, 2004a, pp. 359-371.

[22] Raji A.O., Favier J.F. Model for the deformation in agricultural and food particulate materials under bulk compressive loading using discrete element method. II: Compression of oilseeds. Journal of Food Engineering, vol. 64, 2004a, pp. 373-380.

[23] Gupta G.K., Das S.K. Fracture resistance of sunflower seed and kernel to compressive loading. Journal of Food Engineering, vol. 46, pp. 1-8.

[24] Sigalingging R., Herak D., Kabutey A., Dajbych O., Hrabe P., Cestmir M. Application of a tangent curve mathematical model for analysis of the mechanical behaviour of sunflower bulk seeds. International Agrophysics, vol. 29, 2015, pp. 517-524.

[25] Sigalingging R., Herak D., Kabutey A., Cestmir M., Divisova M. Tangent curve function description of mechanical behaviour of bulk oilseeds: A review. Scientia Agriculturae Bohemicae, vol. 45, 2014, pp. 259-264. 